\title{
BSA Involvement Score 3
}

National Cancer Institute

\section{Source}

National Cancer Institute. BSA Involvement Score 3. NCI Thesaurus. Code C131038.

Greater than $50 \%$ of body surface area involved. 